\title{
Application of Problem Based Learning Assisted by Google Classroom Application to Increase Student Interest in SDN 1 Wonoyoso Students
}

\section{Desi Tri Widiyanti}

SDN 1 Wonoyoso

desiwidiyanti441@gmail.com

\section{Article History}

accepted 01/11/2020

\begin{abstract}
The purpose of this research is to increase students' interest in learning. This research is a classroom action research (PTK) which was conducted in 3 cycles, each cycle consisting of planning, implementation, observation, and reflection stages. The subjects of this study were fourth grade students and fifth grade students of SD Negeri 1 Wonoyoso, Kuwarasan District, Kebumen Regency in the academic year 2020/2021, totaling 28 students. Data collection techniques using observation, questionnaires and tests. Data analysis includes data reduction, data presentation, and drawing conclusions. The research shows that the application of the Problem Based Learning learning model can increase the learning interest and learning outcomes of grade IV and grade V SD Negeri 1 Wonoyoso, Kuwarasan District, Kebumen Regency in the academic year 2020/2021 as evidenced by the percentage of completeness of learning outcomes in cycle I

amounted to $53.6 \%$ to $92.9 \%$ in cycle III
\end{abstract}

Keywords: Interest in Learning, Problem Based Learning model, Google Classroom

\begin{abstract}
Abstrak
Tujuan penelitian ini adalah meningkatkan minat belajar siswa. Penelitian ini merupakan penelitian tindakan kelas (PTK) yang dilaksanakan dalam 3 siklus, setiap siklus terdiri dari tahap perencanaan, pelaksanaan, observasi, dan refleksi. Subjek penelitian ini adalah siswa kelas IV dan siswa kelas V SD Negeri 1 Wonoyoso Kecamatan Kuwarasan Kabupaten Kebumen tahun pelajaran 2020/2021 yang berjumlah 28 siswa. Teknik pengumpulan data menggunakan observasi,angket dan tes. Analisis data meliputi reduksi data, penyajian data, dan penarikan kesimpulan. Penelitian menunjukkan bahwa penerapan model pembelajaran Problem Based Learning dapat meningkatkan minat belajar dan hasil belajar siswa kelas IV dan kelas V SD Negeri 1 Wonoyoso Kecamatan Kuwarasan Kabupaten Kebumen tahun pelajaran 2020/2021 dibuktikan dengan persentase ketuntasan hasil belajar pada siklus I sebesar $53,6 \%$ menjadi $92,9 \%$ pada siklus III.
\end{abstract}

Kata kunci: Minat Belajar, model Problem Based Learning, Google Classroom

Social, Humanities, and Education Studies (SHEs): Conference Series https://jurnal.uns.ac.id/shes 


\section{PENDAHULUAN}

Pembelajaran tematik terpadu merupakan pembelajaran menggunakan tema untuk mengaitkan beberapa muatan mata pelajaran agar dapat memberikan pengalaman bermakna kepada peserta didik (Kemendikbud, 2014). Pada masa pandemi Covid 19, pembelajaran tematik terpadu di SD dilaksanakan secara daring. Pelaksanaan pembelajaran secara daring sekaligus menjadi sarana bagi sekolah untuk mengembangkan keterampilan pembelajaran abad 21, diantarnya adalah keterampilan berpikir kritis dan penggunaan aplikasi berbasis internet dalam pembelajaran. Kurikulum 2013 harus menampakkan proses pembelajaran yang menyenangkan sehingga dapat meningkatkan minat belajar siswa. Muara dari minat belajar pada akhirnya adalah hasil belajar siswa.

Kenyataannya proses pembelajaran yang terjadi di SD Negeri 1 Wonoyoso belum menerapkan model pembelajaran yang menumbuhkan minat belajar. Hasil pengamatan awal menunjukkan bahwa siswa kelas IV dan kelas V SD Negeri 1 Wonoyoso memiliki minat yang rendah dalam pembelajaran, hal tersebut berdampak pada rendahnya hasil belajar siswa. Hasil pengamatan awal terhadap proses pembelajaran siswa kelas IV dan V SD Negeri 1 Wonoyoso menunjukkan bahwa minat belajar siswa pada saat pembelajran masih rendah, mereka merasa bosan dan kurang tertarik. Nilai rata-rata Penilaian Harian Kelas IV baru mencapai 62. Sedangkan Nilai Rata-rata Penilaian Harian Kelas V baru mencapai 60.

Berbagai upaya peningkatan keterampilan berpikir kritis tersebut telah dilakukan, namun belum mencapai hasil, karena belum menerapkan model pembelajaran yang memiliki potensi untuk meningkatkan minat belajar siswa. Berdasarkan hasil kajian pustaka menemukan bahwa model pembelajaran PBL berpotensi untuk meningkatkan minat belajar siswa.

Untuk memperbaiki proses dan minat belajar tersebut, akan diterapkan model pembelajaran PBL berbantuan aplikasi Google Classroom. Alasan mengggunkan aplikasi Google Classroom,aplikasi ini memungkinkan kegiatan belajar mengajar menjadi lebih produktif dan bermakna dengan menyederhanakan tugas, meningkatkan kolaborasi, dan membina komunikasi. Pengajar dapat membuat kelas, memberikan tugas, mengirim masukan, dan melihat semuanya di satu tempat. Diharapkan setelah tindakan pembelajaran dilakukan, rata-rata tingkat minat mencapai $\geq 78 \%$, berada pada kategori tinggi.

\section{METODE}

Penelitian ini merupakan penelitian tindakan kelas (PTK) yang dilaksanakan dalam 3 siklus, setiap siklus terdiri dari tahap perencanaan, pelaksanaan, observasi, dan refleksi. Penelitian ini dilakukan di kelas IV dan kelas V SD Negeri 1 Wonoyoso Kecamatan Kuwarasan Kabupaten Kebumen. Jumlah siswa kelas IV yaitu 24 peserta didik yang terdiri dari 12 peserta didik laki-laki dan 14 peserta didik perempuan. Sedang kan siswa kelas IV berjumlah 20 siswa yang terdiri dari 15 peserta didik lakilaki dan 5 peserta didik perempuan. Sumber data dalam penelitian ini adalah siswa kelas IV dan V SD Negeri 1 Wonoyoso dan teman sejawat sebagai observer selama pelaksanaan perbaikan pembelajaran. Data yang dikumpulkan adalah data kualitatif dan kuantitatif yang terdiri dari data kualitatif berupa data proses pembelajaran, data pemahaman siswa terhadap materi ajar, data respon siswa terhadap penerapan model pembelajaran. Sedangkan data kuantitatif berupa hasil pembelajaran berbentuk nilai tes formatif.

Teknik pengumpulan data yaitu berupa observasi, dilakukan untuk mengamati aktifitas siswa dan guru selama proses pembelajaran, wawancara berupa angket yang dibagikan siswa, dan tes formatif dilakukan untuk mengetahui tingkat penguasaan siswa terhadap materi pembelajaran menggunakan model Problem Based Learning Berbantuan Google Classroom. Data kualitatif akan diolah dalam bentuk paparan 
narasi yang menggambarkan kualitas pembelajaran, sedangkan data kuantitatif akan diolah melalui analisis deskriptif atau analisis data yang dilakukan berdasarkan tes formatif dari Prasiklus sampai tiga kali siklus pembelajaran. Prosedur pelaksanaan PTK dilaksanakan dalam tiga siklus perbaikan.

\section{HASIL DAN PEMBAHASAN}

Berdasarkan analisis hasil penelitian yang telah diuraikan maka pembahasan pada penelitian ini adalah sebagai berikut:

Tabel 1. Peningkatan Penerapan Model PBL

\begin{tabular}{lccc}
\hline \multicolumn{1}{c}{ Aspek } & \multicolumn{3}{c}{ Skor Rata-rata } \\
\hline & KE1 & KE2 & K3 \\
Orientasi peserta didik kepada masalah & 3.3 & 3.7 & 3.7 \\
Mengorganisasikan peserta didik & 3.0 & 3.3 & 3.7 \\
Membimbing,penyelidikan individu dan kelompok & 3.0 & 3.7 & 4.0 \\
Mengembangkan dan menyajikan hasil karya & 3.0 & 3.0 & 4.0 \\
Menganalisis dan mengevaluasi proses pemecahan & & & \\
masalah & 2.0 & 3.0 & 4. \\
Rata-rata & $\mathbf{2 . 9}$ & $\mathbf{3 . 4}$ & $\mathbf{3 . 9}$ \\
Prosentase & $\mathbf{7 3}$ & $\mathbf{8 5}$ & $\mathbf{9 7}$ \\
\hline
\end{tabular}

Penerapan model Problem Based Learning (PBL) yang digunakan pada pembelajaran terus mengalami peningkatan. Peningkatan ini dilihat dari hasil observasi teman sejawat. Peningkatan penerapan model PBL pada siklus 1 baru mendapatkan prosentase $73 \%$, pada siklus 2 meningkat menjadi $85 \%$, kemudian pada siklus 3 mencapai $97 \%$. Penigkatan tersebut dapat dilihat melalui diagram berikut ini.

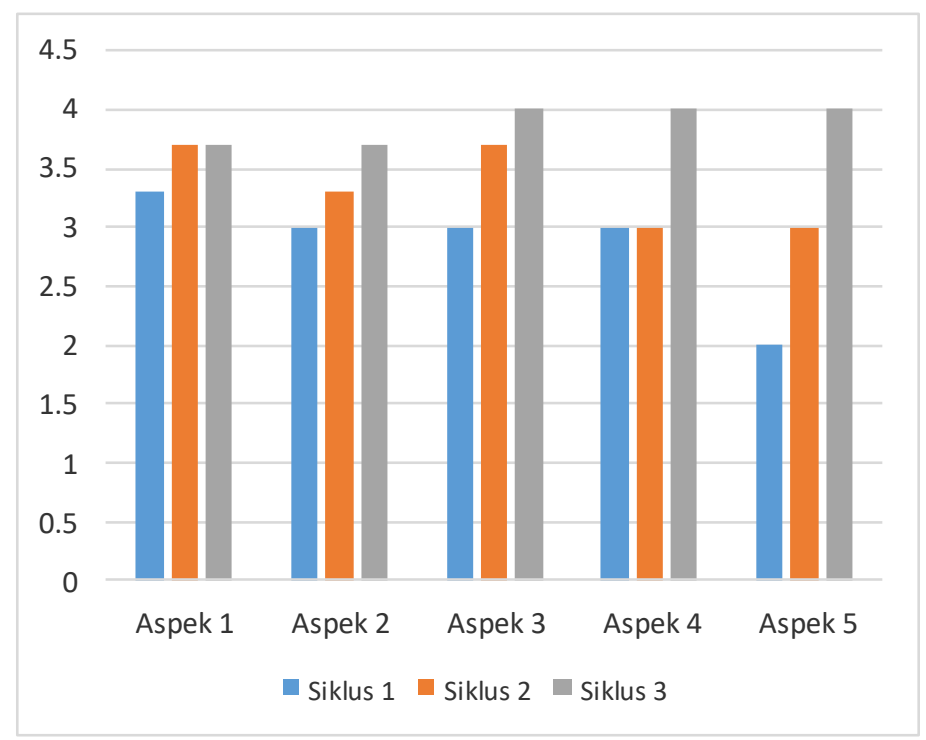

Gambar 1. Hasil Observasi Peningkatan Penerapan Model PBL

Dari diagram diatas menunjukkan bahwa penerapan model $P B L$ mengalami peningkatan dari siklus 1 dengan prosentase $73 \%$, siklus 2 yaitu $85 \%$ dan pada siklus 3 meningkat menjadi $97 \%$. 
SHEs: Conference Series 3 (3) (2020) $238-242$

Dengan adanya peningkatan penerapan model Problem Based Learning akan menambah minat siswa dalam belajar. Hal ini terlihat dari hasil belajarnya. Peningkatan hasil belajar dapat dilihat melalui tabel berikut ini.

Tabel 2. Peningkatan Hasil Belajar Siswa

\begin{tabular}{|c|c|c|c|c|c|c|}
\hline \multirow[t]{2}{*}{ No } & \multirow[t]{2}{*}{ Perbaikan } & \multirow{2}{*}{$\begin{array}{l}\text { Rata- } \\
\text { rata }\end{array}$} & \multicolumn{2}{|c|}{ Tuntas } & \multicolumn{2}{|c|}{ Tidak Tuntas } \\
\hline & & & Jumlah & Prosentase & Jumlah & Prosentase \\
\hline 1. & $\begin{array}{l}\text { Pra Siklus Kelas } \\
\text { IV) }\end{array}$ & 63 & 5 & $21 \%$ & 15 & $79 \%$ \\
\hline 2. & $\begin{array}{l}\text { Pra Siklus (Kelas } \\
\text { IV) }\end{array}$ & 63 & 4 & $20 \%$ & 16 & $80 \%$ \\
\hline 3. & Siklus 1 & 78 & 17 & $71 \%$ & 7 & $29 \%$ \\
\hline 4. & Siklus 2 & 84 & 17 & $85 \%$ & 3 & $15 \%$ \\
\hline 5. & Siklus 3 & 86 & 22 & $92 \%$ & 2 & $8 \%$ \\
\hline
\end{tabular}

Dari tabel diatas dapat disimpulkan bahwa hasil belajar siswa meningkat dari siklus ke siklus. Dari kegiatan pra siklus yang tuntas baru $21 \%$, pada siklus 2 siswa yang tuntas meningkat menjadi $71 \%$, siklus kedua meningkat lagi menjadi $85 \%$, kemudian pada siklus 3 meningkat lagi menjadi 92\%. Peningkatan hasil belajar tersebut dapat dilihat melalui diagram berikut ini.



Gambar 2. Hasil Belajar Menggunakan Model PBL

\section{SIMPULAN}

Berdasarkan hasil analisis dari Prasiklus sampai dengan siklus ketiga, dapat disimpulkan bahwa penerapan model Problem Based Learning (PBL) Berbantuan Aplikasi Google Classroom dapat meningkatkan minat belajar siswa SD Negeri 1 Wonoyoso Kecamatan Kuwarasan Kabupaten Kebumen. Dampak penerapan model Problem Based Learning (PBL) Berbantuan Aplikasi Google Classroom adalah dapat meningkatkan minat belajar siswa sehingga hasil belajar siswa juga meningkat.

Peneliti hendaknya menerapkan model pembelajaran yang sama untuk mengatasi permasalahan pembelajaran yang sama. Peneliti juga harus selalu menggunakan media pembelajaran yang menarik dan menggunakan aplikasi yang menunjang pembelajarn siswa sehingga membantu memudahkan siswa memahami materi untuk mengatasi permasalahan pembelajaran yang sama. 


\section{DAFTAR PUSTAKA}

Arends, R. (2008). Learning to Teach, Terjemahan oleh Helly Prajitno \& Sri Mulyani. New York: McGraw Hill Company.

Eni Wulandari, Setyo Budi \& Kartika Chryati. (2013). Penerapan Model PBL pada Pembelajaran IPA Siswa Kelas V SD. Jurnal Kalam Cendekia PGSD Kebumen, $2(1): 13-17$.

Manis. (2019). Pengertian PTK, Tujuan, Karakteristik, Prinsip, Langkah dan Model Penelitian Tindakan Kelas (PTK) Lengkap. Pelajaran.co.id. Diakses dari https://www.pelajaran.co.id/2019/15/pengertian-ptk-tujuan-karakteristik-prinsiplangkah-dan-model-penelitian-tindakan-kelas-ptk.html

Muhammad Yaumi \& Muljono Damopolli. (2014). Action Research: Teori, Model,dan Aplikasi. Jakarta: Kencana PrenadaGroup.

I Gede Agus Siswantara, I.B. Surya Manuaba \& I Gede Mater (2013). Penerapan Model Problem Based Learning (PBL) Untuk Meningkatkan Aktivitas dan Hasil Belajar IPA Siswa Kelas IV SD Negeri 8 Kesiman. Jurnal Garuda Portal 1(1):110.

Kemendikbud. (2014). Materi Pelatihan Guru Implementasi Kurikulum 2013 Tahun 2014. Jakarta: Badan Pengembangan Sumber Daya Manusia Pendidikan dan Kebudayaan dan Penjaminan Mutu Pendidikan - Kementerian Pendidikan dan Kebudayaan.

Riska Apriani. (2013). Peningkatan Pembelajaran Perubahan Lingkungan melalui Model Problem Based Learning pada Siswa kelas IV SD Negeri Randugunting 3-KotaTegal. Semarang: UNNES

Suharsimi Arikunto,Suhardjono \& Supardi. (2010). Penelitian Tindakan Kelas. Jakarta: Bumi Aksara. 